\title{
Bringing together Anthropology, Ethnology and Folklore: From Factions to Union
}

\author{
LAURENT SÉBASTIEN FOURNIER \\ IDEMEC UMR 7307 CNRS - Aix-Marseille-Université
}

\begin{abstract}
In this paper I first focus on the foundation of the AFEA (Association Française d'Ethnologie et d'Anthropologie) and I try to find out how this new association has been managing (or not) to bring together anthropology and folklore since its foundation in 2009. Using this French example, I also try to shed light on more global discussions going on between folklorists, ethnologists and anthropologists worldwide. I present different models of possible cooperation between anthropologists and folklorists, ranging from unitarism to federalism. Finally, I question the relevance of dualist schemes in our field of studies.
\end{abstract}

Keywords: associations, folklore, ethnology, anthropology, dualism

\section{INTRODUCTION}

In France, folklore does not appear as an official discipline in the academic curricula. The only headings the university proposes are social anthropology or cultural anthropology. Ethnology is usually considered a part of the anthropology curriculum. These two disciplines are strongly connected although they do not focus on the same thing: ethnology is interested in the diversity of cultures and anthropology studies the unity of man. The absence of ethnology and folklore is due to different reasons. First, there is a strong tradition of anthropology in France because of the colonial past of the country. A lot of anthropologists have not come back from the colonies until the 1970's, after the decolonization process was completed in Maghreb and in Western Africa. They have since applied anthropological methods to Occidental societies, and the field of European ethnology and folklore has then merged with the field of European anthropology. Second, anthropology has been considered more fashionable than folklore after Lévi-Strauss's statements according to which it is a more general and a more theoretical discipline. As already stated, anthropology deals with the man in general 
whereas ethnology and folklore deal with cultures in the plural. Thanks to Lévi-Strauss, in the post-World War II period anthropology managed to build up strong ties with linguistics and literature studies through structuralism, whereas ethnology and folklore remained mainly descriptive. Given that the French political doctrine is strongly universalistic, it is generally assumed that the anthropological point of view fits better with the French national spirit. Ethnology and folklore are sometimes even frowned upon as subversive, because they would encourage diversity more than unity. They would therefore help regional claims more than the central nation-State, which is not acceptable to the Parisian intellectual elites. Third, folklore and European ethnology, as in many other countries, have often been suspected of reinforcing regionalism and parochialism. It is often said that these disciplines are more easily instrumentalized and can be politically biased. In the history of our disciplines, this was evident in France under the Vichy regime, which collaborated with the German occupiers during World War II and did a lot to develop folklore, especially through "folklorism", staged folklore, and cultural programs emphasizing regional traditional cultures (Faure 1989).

These different reasons are intertwined, and roughly explain why folklore and anthropology rarely cooperate in France. Anthropologists usually suspect folklorists of being amateurish and of overemphasizing the local, whereas folklorists do not use the comparative dimension of anthropology. Ethnology is usually considered a part of the anthropological method rather than a distinct discipline. However, in recent times, the scarcity of resources, the lack of stable jobs in the academia and the fashion for interdisciplinary studies have led to some changes, and it may be the right time to start a debate concerning possible cooperation between these disciplines in the future.

Furthermore, such a debate also has much broader importance because it can shed light on the politics of knowledge and disciplinarity in contemporary social sciences. Many theorists of knowledge have addressed this debate in their own terms. For Berger and Luckmann (1966), for instance, persons and groups interacting in a social system create concepts or mental representations of each other's actions, and these concepts eventually become habituated into reciprocal roles played by the actors in relation to each other. Like other fields of common knowledge, social sciences are socially constructed by their actors, both authors and readers in this case. Similarly, Kuhn (1962) has shown the importance of "paradigm shifts" in sciences and their permeability in the historical context. The notion of scientific truth, Kuhn suggests, cannot be established objectively but relies on the definitions of scientific truth the scientific community offers at a given moment in time. Building on these constructivist theories, Bourdieu went further and suggested that the structure of any social field was deeply dependent on the ac- 
tors' individual "habitus"; the notion presupposing that any individual agent embodies and develops specific dispositions in response to the objective conditions he encounters. Following Bourdieu's study of his own colleagues in his book Homo academicus (Bourdieu 1984), in this article I propose to consider the connected disciplines of anthropology, ethnology and folklore as a dynamic "field" in which the agents and their social positions are located, and may dramatically change. In this perspective, the structure of the connected fields of anthropology, ethnology and folklore is defined by the interactions between the specific rules of the fields, the individual habitus of the agents and their social, economic and cultural capital in connection with the disciplinary canons. Next, coming back to Kuhn's analyses, is it possible today to speak of a "scientific revolution" bringing together our connected disciplines? And then, what would be the structure of such a revolution?

In order to contribute to this general debate about the possible cooperation of anthropology, ethnology and folklore, in this article I would like to focus on the following points. First, I will present the case of the "Association Française d'Ethnologie et d'Anthropologie" (AFEA), ${ }^{1}$ a young member association of the World Congress of Anthropological Associations (WCAA), ${ }^{2}$ founded in 2009 in France. I will use this French case-study in order to work out the debate at a national scale, and I will examine how and if the new association really manages to bring together anthropology, ethnology and folklore. Second, I will move to a broader view, and compare the case of this association with echoes I have had from more global discussions going on between the WCAA and the International Union of Anthropological and Ethnological Societies (IUAES), ${ }^{3}$ and I will present different models of possible cooperation between professional associations, ranging from unitarism to federalism. This will provide an opportunity to assess the relevance of the two different models: whereas the advocates of unity consider it better to eliminate the different existing bodies and establish a new one, the advocates of federalism prefer the existing associations to remain active in the new structure, and to keep their distinct voice in it. At this point, I will suggest that the discussion between the different possible options is always a complex one, because it simultaneously refers to values, ethics, general preconceptions regarding citizenship and social relations, as well as to individual strategies and to the struggles for power between the different actors in the field actually being restructured. Third, I will question the relevance of dualist schemes in professional organizations, trying to apply the anthropological analysis of the notions of conflict and differentiation

\footnotetext{
${ }^{1}$ http://asso-afea.fr/

${ }^{2}$ http://www.wcaanet.org/

${ }^{3}$ http://www.iuaes.org/
} 
to the case of anthropology as well as to ethnological and folklore professional associations. Specifically, I will use the metaphor of identity politics and conflict theories developed by the most widely accepted sociologists and political anthropologists (Simmel 1918; Evans-Pritchard 1940) in order to better understand what is at stake in the building up of a scientific field, when people advocate unitarism or federalism. Finally, I will use the notions of heritage and utopia in a self-reflexive way to reflect on the heritages and utopias that folklorists, ethnologists and anthropologists could share today. This point will eventually lead to the questioning of the sense of community in these connected academic fields.

\section{THE CASE OF THE “ASSOCIATION FRANÇAISE D'ETHNOLOGIE ET D'ANTHROPOLOGIE” (AFEA)}

As I have said before, in France in the past, the fields of folklore, ethnology and anthropology were somewhat set apart. Because of political issues during World War II, for instance, folklore was deeply criticized because of its connections with conservatism and the far-right. The "Société de Folklore Français et de Folklore Colonial" was re-named "Société d'Ethnologie Française" (SEF) 4 in 1946, just after the war. At that time, it was important to show that "folklore" and especially "colonial folklore" were no longer at the heart of the discipline. Showing an interest in the "other" more than in the "self" marked a turning point in "ethnology". The new society worked within the auspices of the "Musée national des Arts et Traditions populaires" in Paris and established its network by creating strong ties with this museum, which had been founded before the war, under a leftist government. ${ }^{5}$ Some of its members, including Georges Henri Rivière and Roger Lecotté, were members of the "Commission Internationale des Arts Populaires" (CIAP), which worked under the aegis of the "Sociéte des Nations" before the war. They, along with some others, took part in the foundation of the "Société Internationale d'Ethnologie et de Folklore" (SIEF) in 1964.

In contrast, anthropology was able to face modernity better than folklore. ${ }^{6}$ It was also criticized, because physical anthropologists had focused on race and had been suspected of racism, but it soon managed to establish

\footnotetext{
${ }^{4}$ http://sef.hypotheses.org/

${ }^{5}$ For the history of Musée national des Arts et Traditions populaires, see the book by Martine Segalen (2005).

${ }^{6}$ Unfortunately nobody has really worked on the history of French ethnological and anthropological associations after World War II. However, some good remarks on ethnology and folklore from a French perspective can be found in the book edited by Christophe et al. (2009). For an "outsider" perspective concerning anthropology, I also recommend the work by Susan Carol Rogers (2002).
} 
a relationship with structuralism, with theoretical Marxism and with other social sciences such as sociology and history. The "Association Française des Anthropologues" (AFA) ${ }^{7}$ was founded in 1979 after a conference concerning the situation in anthropology and its future. Since then, it has been claimed to be more politically engaged and more theoretical than the SEF. Besides these two central national organizations, SEF and AFA, different sectorial associations have appeared in both fields in the last decades. For instance, on the anthropological side, the association "Anthropologie Médicale Appliquée au Développement et à la Santé" (AMADES) ${ }^{8}$ is active in the field of medical anthropology, whereas the "Association Euro-Africaine pour une anthropologie du changement social et du développement" (APAD) ${ }^{9}$ works in the sector of economic development. Still on the anthropological side, another generalist association called "Association Pour la Recherche en Anthropologie Sociale" (APRAS) ${ }^{10}$ was founded in 1989, and struggled against the AFA, which was considered too politically engaged. On the ethnology and folklore side, other sectorial associations exist, such as the "Société Française $\mathrm{d}^{\prime}$ Ethnomusicologie" (SFE) ${ }^{11}$ at the national level or smaller folklore associations in the different regions.

To sum up the situation, there are dozens of associations in France, all having NGO statutes following the 1901 Associations Act and being more or less connected with universities, museums and public research institutes, as the case may be. They are all independent, and decide on their own fate through regular meetings and conferences. Their size ranges from only a few members to several hundred in the case of bigger ones like the AFA. All these associations elect their own boards and solicit subsides from the French State or from local and regional governments and/or institutions.

In 2007 there was a long struggle and a series of strikes in the public research and university sector in France during the presidency of Nicolas Sarkozy. Many anthropologists and ethnologists decided to react to the ideology of the "new public management" which, according to them, was severely threatening social sciences. Social scientists felt especially threatened after the passing of the 2007 "LRU" Act (Loi relative aux libertés et responsabilités des universités), which dramatically increased the power of university presidents. According to this law, different universities could concentrate only on the more profitable sectors. Due to the economic crisis, the French right-wing government decided to no longer sponsor those disciplines which could not generate immediate profit and secure employment to its graduates. There

\footnotetext{
${ }^{7}$ http://www.afa.msh-paris.fr/

${ }^{8}$ http://amades.hypotheses.org/

${ }^{9}$ http://apad-association.org/

${ }^{10}$ http://www.mae.u-paris10.fr/apras/

${ }^{11}$ http://www.ethnomusicologie.fr/
} 
was an immediate reaction in the humanities and social science sectors to support the "less profitable" disciplines, with claims being made that their profit was more of a long-term profit and that they were the most important at a cultural and even a civilizational level. In the case of anthropology, there was a general meeting in December 2007 in Paris called "les Assises de l'anthropologie" (National Conference for Anthropology). ${ }^{12}$ The debates concerned the changes in the public management of teaching and research, possible interactions between disciplines to resist these changes, the role and the involvement of anthropologists in the public sphere, ways of building up otherness, and professional organization of the discipline. Based on these debates, the decision was reached to establish a new organization, the "Association Française d'Ethnologie et d'Anthropologie" (AFEA).

The bylaws of the new association were drawn up in 2009 and the association has since organized two congresses: the first one at the EHESS in Paris in 2011, and the second one at the University of Toulouse in 2015. The new association aims to promote the plurality of the discipline, its growth, its practices, its transmission and its future as a fundamental as well as an applied discipline. According to its bylaws, 24 people make up its Board, 12 of whom are individually elected members and 12 of whom represent the different associations which are members of the AFEA.

From the beginning, however, there has been an ongoing debate concerning the role that the different member associations should have within the AFEA overarching structure. Some people, especially for the younger generations and colleagues who were not already involved in other existing associations, consider the AFEA to be a new way for anthropologists and folklorists to speak in a single voice, and they believe that all the smaller associations should disappear in the new larger organization. However, other people believe that it is important to keep the older associations, particularly those that publish journals and are already well-identified in the field. From this perspective, according to many board members of the older existing associations, the AFEA would be a powerful tool to reinforce the action of the existing associations and to promote diversity within the discipline. Accordingly, some associations, like the APRAS, have chosen to dissolve themselves and integrate into the new association, whereas others, like the AFA, the SEF and some other sectorial associations, have decided to remain active and to join the board of the new association. As usual, these decisions also coincided with the political interests of the different associations, some of them preferring to become part of the new association, and others choosing to remain active and impose their views on the new board.

\footnotetext{
${ }^{12}$ http://assisesethno.org/
} 
Since the foundation of the AFEA in 2009 the discussions on the role that the member associations should have in the new structure have never stopped. During the last congress in 2015, some people have decided to leave the new association, because they believed that its management was nothing but a waste of time which led to weakening of the older associations. Since the last congress, AFEA members have been struggling to get a sufficient number of associations back on board to fill the vacant seats. Only a few years after its foundation, the assessment of the AFEA reveals rather disappointing results. Smaller associations, new generations and people without stable positions in the academia really believed that it was important to invest in the new association, while bigger associations, older generations and the most established academics usually came to the AFEA in order not to be left behind, but remained sceptical about its ability to really bring about far-reaching changes. However, the story of the AFEA is an interesting one because it shows that the divisions into disciplinary subfields have been far but central in the debates. Indeed, it was no problem at all to unite anthropologists, ethnologists and folklorists around the idea of a new association, but there have been many more problems in finding out how to manage the new association. This experience leads to the following statement: it is not a problem to unite different contents, areas of studies or fields of research, but to decide which model of cooperation would be better accepted by the people involved in the unification process.

\section{TOWARDS AN INTERNATIONAL COMPARISON}

Having this French experience in mind, as an executive board member of the SIEF, I was very interested when our WCAA liaison officer Clara Saraiva told us about the discussions concerning a possible relationship between the WCAA and IUAES. These discussions took up a great part of the WCAA biannual meeting in Taipei, October $1^{\text {st }}$ and $2^{\text {nd }} 2014$, where anthropologists discussed their strategies to get a better audience and to promote the impact of the discipline on the society at large. On the one hand, the advantages of an alliance between the two international organizations were examined, emphasizing the idea of a "truly global community of world anthropologists" and the importance of "a unified global voice for anthropology". ${ }^{13}$ On the

${ }^{13}$ I am grateful to Clara Saraiva who provided me with the minutes of this meeting. For further information, see Vucinic Neskovic (2015). For a comprehensive analysis of the situation on the international level, the collective forum "Rethinking Euro-Anthropology" published by the journal Social Anthropology/Anthropologie Sociale in 2015, is an important milestone pointing to the various ways of practicing anthropology today, the importance of dissemination, the relations between the different disciplines of the field etc. 
other hand, some concerns were raised because of different reputations of the two organizations. The WCAA was founded in 2004 as a new operational network of associations and organizations, whereas the IUAES is much older (founded in 1948), well structured, and brings together national institutions and individual researchers. Other concerns were about the financial consequences of a union.

Moreover, two possibilities were examined in the case of "coming together", the first one being a unification, the second a confederation. Again, in this case, the discussions had two different dimensions: a strategic one, related to the identities of the organizations involved in the merging process, and a more technical one, related to the feasibility and the possible options to follow. There was also a practical difference between the two options: in the case of a unification, the founding bodies would disappear and a new one would be formed, but in the case of a confederation, the founding associations would remain active and have a distinct voice in the new structure. At the end, a "tricameral merger proposal" was presented in order to build up a unified structure for IUAES and WCAA. The proposition was a compromise, providing a way to work together while still enabling both partners to keep their own chambers. A third chamber would simply be added in order to make a junction between the two existing associations without weakening their own powers. Even if the result of this process is still uncertain, I suggest that this sort of discussion is important and interesting because it documents the politics of anthropology. Following Bourdieu (1979), it teaches us about the structure of the "field" of anthropology and about the struggles existing within this specific field of social sciences.

In a recent newsletter, the WCAA has reported on the discussions which followed the Taipei meeting at the IUAES inter-congress in Bangkok, July $15^{\text {th }}$ to $18^{\text {th }} 2015$. A WCAA-IUAES Task Group has been constituted. It has held several Skype meetings since 2013 and has prepared the draft constitution of the new body, the WAU (World Anthropological Union). In this new umbrella structure, the WCAA and IUAES would be two "chambers". The draft constitution carefully gives an equal number of seats to both chambers and proposes "a memorandum of agreement, which would preserve the independence of the two organizations at the present level, but intensify their collaboration" (WCAA Bulletin, 2015: 4). Obviously, the discussions are mostly political, and they concern the preservation of the existing bodies and of their representatives. Strangely, the definition of the discipline is taken for granted, and the debates concentrate on the diplomacy of science much more than on the contents of the different sub-disciplines themselves. Going back to Kuhn's analyses, would the revolution, then, be much more a political one than a scientific one? 
The archives of the different existing anthropological and ethnological societies enable us to trace back similar debates and discussions in the past. To take a single example, I will refer to the excellent article by Bjarne Rogan, who has, in a recent number of Cultural Analysis, examined the history of SIEF in great detail (Rogan 2014). Just like in the previous case, Bjarne Rogan also shows the importance of politics in 1964 when the SIEF was founded. He even suggests that the foundation of SIEF might have been altogether political. In 1964, the discussion centred on the relationship between ethnology and folklore, with two possible options. The faction led by the Swedish ethnologist Sigurd Erixon considered ethnology and folklore different specialties of a single common discipline, while the one led by the German folklorist Kurt Ranke believed that they should be considered as independent. Rogan explains how the folklorist minority led by Ranke, together with the members of the newly founded International Society for Folk Narrative Research (ISFNR), managed to arrange a "putsch" and to assume power, defeating Erixon's faction and the older Commission Internationale des Arts Populaires (CIAP), which defended the idea of a unified European ethnology where anthropology and folklore would be branches of a common discipline rather than disciplines in their own right (Rogan 2014: 24-25). In this case, the enemies of Erixon's unification project came from within, especially from the ranks of folklorists and the Volkskundler led by Ranke, who desperately needed SIEF to professionalize folklore at the time. Rogan's analyses of the archives ultimately show that content mattered less than the respective positions of the different actors and their struggles to dominate the field or to prevent internal "enemies" from dominating it.

Coming back to the present and to the process of fostering cooperation or of creating a new sense of community uniting anthropology, ethnology and folklore today, I would suggest that the debate has to take into account not only national case studies like the French one I have presented above, but also comparative vistas at a more global level. Thus, the more difficult part of the task is not to find correspondences between anthropology, ethnology and folklore, but rather to build up a cooperative platform in general. Indeed, our disciplines are not fundamentally different from each other, and as neighbouring disciplines they have a lot to share. Such discussions had already taken place in the beginnings of the history of these disciplines, leading some specialists to question the terminologies of the different existing subfields and to consider their possible hybridization (Cocchiara 1952). In the $19^{\text {th }}$ century, most of the authors used the comparative methods of anthropology when doing folklore, and the ethnographic methods of folklore when doing anthropology. For instance, a folklorist like Lady Gomme, when collecting traditional games in England, always tried to explain them by using the evolutionist anthropological theories of her time, and ordered her 
data according to the general scales of evolutionism (Gomme 1894). On the anthropological side, it is interesting to see how Sir Frazer's "grand theory" of the history of religions relied both on exotic and on folkloric European data (Frazer 1906). Similarly, in the history of French anthropology, connections between anthropology and folklore are evident, for instance in Arnold Van Gennep's "rite de passage" concept, where he shows that rituals are conceptualized in a similar way in exotic and in European societies (Van Gennep 1909). Of course, these authors used different names to designate what they were doing. But from a purely scientific standpoint, it is usually accepted that anthropological studies can be usefully completed by using ethnological and folkloric data, and that ethnological and folkloric research can find a lot of profit when it uses a comparative anthropological perspective.

However, it becomes very different when you ask people about the way they could cooperate. In other words, the problem is not with the content and with the idea of cooperation in itself, but with methods, because they are closely connected with personal ethics and individual beliefs as to the best possible way of collective engagement. The problem here is that different cooperative models exist, and that each of us spontaneously thinks about some of these models as being better than others, more efficient or more moral. This is why the debate between the unitarist versus the federalist option is so important in every case. The debate refers to our individual political education and to our individual preconceptions of citizenship, and not to the content of the specialized field of studies in which we are engaged. In this respect, among anthropologists as well as among ethnologists or folklorists, and among any group of people in general, I suppose, one is likely to find advocates of unitarism as well as advocates of federalism. The first step in building up a sense of community might then be to initiate a comprehensive debate on what unitarism and federalism mean at an individual level. Moreover, the support of unitarism or federalism can also correspond to specific individual strategies and reflect the positions of power and the already established niches where the different leading figures are already engaged. In this respect, politics is not only a matter of values and ethics. It is also linked to individual strategies used to build a community, to individual "habitus" and tastes, and to struggles for power in a given field of studies.

\section{DUALIST SCHEMES AND SELF-REFLEXIVITY}

Drawing on this, I would like to suggest that a comprehensive debate on unitarism and federalism in our connected disciplines can be initiated based on the notions and categories worked out by folklorists, ethnologists and anthropologists themselves. Who better to frame the debate than specialists 
in these disciplines, who have studied the structures of social organizations, including the notions of unitarism and federalism? This has been a key chapter in monographs long before anthropology, ethnology and folklore separated from each other, and can help us to better grasp what is at stake when people advocate unitarism or federalism.

To make this point clearer, I will only refer to several conflict theories which have dealt with the structures of social organizations in the history of our disciplines. In this respect, I find Georg Simmel's theory of conflict very inspiring, because it helps us realize that conflicts are even more intense when people know each other better. According to Simmel (1918), the worst conflicts always happen between immediate neighbours or between married couples. Sometimes the reasons of the conflict are unclear, but this does not prevent the conflict from happening, just because performing the conflict itself is more important than the reasons for it. In Simmel's eyes, conflict is part of the social dynamic itself. It sets things and leads its protagonists to strengthen their position.

Evans-Pritchard (1940) is not very far from Simmel's statements when he theorizes about the notion of "feud" through the ethnography of identity struggles among the Nuer of the Nile valley in Sudan. He was the first to explain that identity is always a relative notion, and I can easily apply his theory to my own position. When I am facing an international audience I will define myself as French, but in France I would rather say I am from Provence, the south of France, to differentiate myself from northerners and Parisians. In Provence I would say I am from a specific village in order to differentiate myself from other villages or towns. And in my own village I would say I am from a specific district, or from the mountainous part of the village as opposed to the flatland, or from the countryside as opposed to the burgh. Based on this logic, identity is a moving process. It changes according to context, which means that the more limited the audience is, the more important the differentiation. Simmel and Evans-Pritchard are useful in understanding identity politics in the academic milieu. In the case of the international societies I have mentioned before, it is interesting to observe that the SIEF, for instance, has strong ties with other international societies but much weaker ones with different national folklore associations. The SIEF looks to international societies for alliances precisely because they are international, but by doing so it works together with other disciplines like social anthropology; whereas no specific ties connect the SIEF with national or local associations working in the very field of ethnology and folklore.

In monographs, authors such as Max Gluckman (1954) for Africa or Ronald Frankenberg (1957) for Wales have shown the importance of conflict dynamics in small communities. In the Welsh community studied by Frankenberg, for instance, conflicts are so strong that the different factions 
prefer to elect someone from outside the community rather than a member of any of the different factions from the village. Here, I would like to suggest that our academic disciplinary communities, with only a few hundreds of colleagues, are not much larger than the small communities traditionally studied by anthropologists, and that the theoretical models built up by social scientists to understand the world outside the academia could be applied to our own case too. Indeed, considering the French situation again, societies such as the Société d'Ethnologie Française (SEF) or the Société Française d'Ethnomusicologie (SFE) have often elected sociologists or music specialists as their presidents, even if they did not have complete training in ethnology or anthropology.

A few years ago, in an article concerning the future of European anthropology, I suggested that the accepted results of our studies should be used to the profit of specialists in these disciplines. In that article, I stated: "If social scientists could enact their theories, they would be able to transport their theoretical knowledge of human organizations to their own disciplinary cultures and interdisciplinary borders, centers and peripheries, so that professional associations could cooperate better and show to policy makers all the benefits they can draw from collective programs across disciplines" (Fournier 2008: 47-48). With this statement, my idea is that our disciplines, however different they are, should always keep in mind the horizon of effectiveness and seek for more recognition by the non-scientific institutions and by the audience at large. Going back to Evans-Pritchard's theory again, when facing an audience of social scientists only, I might say I am a folklorist or an ethnologist rather than an anthropologist, but these differences do not make much sense when I am facing an audience of chemists or an audience of urban planners or managers.

As a consequence, notions such as conflicts, identities and differentiation should be considered through the lens of accepted anthropological knowledge if we want to better understand the problems academic communities face when trying to build up new projects and professional dynamics. To put it in simpler terms, it is not a surprise, according to Simmel's theory, if neighbouring academic fields such as folklore and anthropology are often in conflict. Similarly, following Evans-Pritchard, it is not a surprise if a folklorist is more interested in trying to differentiate oneself from an anthropologist who lives in the same house than from a historian or a literature specialist who live in other villages or countries. Theories of conflict, applied to games and sports, clearly show that competition is stronger in derbies when two neighbouring towns are competing, than in other cases. Competing with a neighbour raises questions of honour and reputation, which are less present when one competes against strangers. But from an outsider point of view, this sort of competition is simply pointless. Therefore, it is paramount 
to remember that we are not alone and that outsiders need a few simple shared features to define us, what we are doing and looking for. Complying with this unspoken requirement does not mean accepting stereotypes and limiting our disciplines to the minimum standard. It is merely the best way to be more efficient and easily recognizable as a group.

An important consequence of this discussion is that all the conflicts and identity struggles happening in the academia might just be an inescapable part of the game. They might just be structural and connected with the vicinity of the different fields. It would then be pointless to prevent them in a modern and rationalist way, especially if we consider academic disciplines to be small communities more than global societies, borrowing the famous distinction between "Gesellshaft" and "Gemeinshaft" from the German philosopher Ferdinand Tönnies (1887). It might just be a wrong perspective to think about academia as a global society and to try to play the game of global societies. If academic disciplines are like small communities, they should be able to share values, to work together, to help each other, to fight against their common enemies, and to remember that their internal conflicts are just structural and inescapable. In such a context, it would be a mistake to take political divisions and the related doctrines of unity and diversity or of unitarism and federalism too seriously when building up representative professional associations. Knowing what they know about social organizations, social scientists should thus be able to apply a more critical and self-reflexive view to their own practices in order to get a larger audience outside their own disciplinary circles.

\section{CONCLUSION}

In conclusion, I sometimes wonder if I am not building a new utopia when I call for a new understanding of our connected fields of study as a "community". However, I am quite sure that a strong cooperation needs a shared heritage, and that a lot of historical struggles need to be overcome in order to reach new efficiency in our disciplines. In this paper I have tried to suggest that the theories used in the fields of folklore, ethnology and anthropology are strong enough to be applied to our own professional academic groups. These theories seem fit to feed a self-reflexive view of our own professional practices. They may enable us to build a more comprehensive view of our field of knowledge, completing the epistemic views on the politics of knowledge popularized by thinkers such as Kuhn or Bourdieu a few decades ago. They also invite us to work out the debate of unity versus diversity in our disciplines at different levels. Such a debate is important at a national level in the different countries but also at a more global level. It raises questions 
of power relationships, given that different nations have developed the fields of anthropology, ethnology and folklore in very different ways according to their own historical contexts. I ultimately suggest that we should use our heritage, our knowledge concerning the complexity of social organizations, to reinforce the sense of community uniting our different fields of studies. In this perspective, conflicts are unavoidable, diversity is a strength, but we also have to remember our unity when we face our enemies. On a practical ground, this means our internal struggles have to be considered for what they are: the result of a too important proximity. However, when we face outsiders, we have to remember our unity and the lessons of our founding fathers. This is the only way to achieve our "scientific revolution" and to reach better integration of the connected disciplines of anthropology, ethnology and folklore.

I would like to finish this article with a quotation from the French philosopher Montaigne: "science sans conscience n'est que ruine de l'âme" - science without consciousness is but the ruin of the soul - which clearly means that we have to be conscious of the results our science enables us to reach, and that we should always apply to ourselves the findings of our own science. Internal struggles and factions are needed because they mean the field is dynamic, but at the same time it is important to remember our common features as well as to unite in order to meet the requirements of the outside world.

\section{REFERENCES AND SOURCES}

Berger, Peter L. and Thomas Luckmann. 1966. The Social Construction of Reality. New York: Anchor Books.

Bourdieu, Pierre. 1979. La distinction. Paris: Editions de Minuit.

Bourdieu, Pierre. 1984. Homo academicus. Paris: Editions de Minuit.

Christophe, Jacqueline et al., eds. 2009. Du folklore à l'ethnologie. Paris: Maison des Sciences de l'Homme.

Cocchiara, Giuseppe. 1952. Storia del folklore in Europa. Torino: Einaudi.

Evans-Pritchard, Edward. 1994 [1940]. Les Nuer. Description des modes de vie et des institutions politiques d'un peuple nilotique. Paris: Tel-Gallimard.

Faure, Christian. 1989. Le projet culturel de Vichy. Lyon: Presses Universitaires de Lyon.

Fournier, Laurent Sébastien. 2008. "Comparing Comparisons in Europeanist Anthropologies. Towards a New Effectiveness in Europeanism". Ethnologia Europaea 38-1: 42-49.

Frankenberg, Ronald. 1957. Village on the Border. A Social Study of Religion, Politics and Football in a North Wales Community. London: Cohen and West.

Frazer, Sir James. 1906. The Golden Bough. London: Macmillan.

Gluckman, Max. 1954. Rituals of Rebellion in South-East Africa. Manchester: Manchester University Press. 
Gomme, Lady Alice Bertha. 1894. The Traditional Games of England, Scotland and Ireland. New York: Dover Publications.

Kuhn, Thomas S. 1962. The Structure of Scientific Revolutions. Chicago: Chicago University Press.

Rogan, Bjarne. 2014. "When the Folklorists Won the Battle but Lost the War. The Cumberstone (Re-)Birth of SIEF in 1964". Cultural Analysis 13: 23-50.

Segalen, Martine. 2005. Vie d'un musée. Paris: Stock.

Simmel, Georg. 1995 [1918]. Le conflit. Belval: Circé-Poche.

Rogers, Susan Carol. 2002. "L'anthropologie en France". Terrain 39: 141-162. [http://dx.doi. org/10.4000/terrain.1476]

Tönnies, Ferdinand. 2005 [1887]. Gemeinschaft und Gesellschaft. Abhandlung des Communismus und des Socialismus als empirischer Culturformen. Darmstadt: Wissenschaftliche Buchgesellschaft.

Van Gennep, Arnold. 1909. Les rites de passage. Paris: Picard.

Vucinic Neskovic, Vesna. 2015. "A United Voice for World Anthropologies". Social Anthropology/Anthropologie Sociale 23: 507-509.

World Council of Anthropological Associations. 2015. 150 Bulletin - Newsletter, $\mathrm{n}^{\circ} 2$ (December).

\section{ZDRUŽIVANJE ANTROPOLOGIJE, ETNOLOGIJE I FOLKLORISTIKE: OD FRAKCIJA PREMA SAVEZU}

Članak započinjem opisom nastanka Francuskog društva za etnologiju i antropologiju (AFEA), na temelju čega prikazujem stanje u području folkloristike i antropologije u Francuskoj. Godine 2007. donesena je odluka o osnivanju nove nacionalne organizacije: AFEA. Ipak, od samog su se početka vodile rasprave o njezinoj ulozi. Je li njezin cilj ujediniti postojeća društva ili biti federacija u kojoj će postojeća udruženja i dalje imati aktivnu ulogu? Imajući na umu to francusko iskustvo, raspravljam o mogućim odnosima između Svjetskog kongresa antropoloških udruženja (WCAA) i Međunarodnog saveza antropoloških i etnoloških društava (IUAES) te se bavim sukobima koji se javljaju u području društvenih znanosti. Na temelju povijesti Međunarodnog društva za etnologiju i folkloristiku (SIEF) propitujem moguću suradnju između zagovornika unitarizma i zagovornika federalizma. Zatim sugeriram da je sveobuhvatnu raspravu o unitarizmu i federalizmu moguće voditi ako se uzmu u obzir pojmovi i kategorije koje predlažu sami etnolozi i antropolozi. Navodim nekoliko teorija konflikta koje su se bavile strukturom društvenih organizacija u povijesti naših disciplina te konstatiram da prihvaćene rezultate tih istraživanja valja koristiti za dobrobit stručnjaka u našim disciplinama.

Ključne riječi: udruženja, folkloristika, etnologija, antropologija, dualizam 